Arts marketing framework: The arts organisation as a hub for participation

February 2017

\author{
Authors: \\ Ria Wiid ${ }^{1}$ \\ r.wiid@worc.ac.uk \\ Paulo Mora-Avila ${ }^{1}$ \\ p.moraavila@worc.ac.uk \\ ${ }^{1}$ Worcester Business School \\ University of Worcester \\ United Kingdom
}




\title{
Arts marketing framework: The arts organisation as a hub for participation
}

\begin{abstract}
The proliferation of artistic content, increased mobility of people, ethnic diversification, and increased scarcity of time outside of work against a backdrop of austerity requires an integrated approach to marketing within the arts. This paper proposes a framework for the marketing of arts based on participation, co-creation and social networks. Additionally, the framework considers the role of self-construal in the participation of arts.
\end{abstract}

“Art is a nation's most precious heritage. For it is in our works of art that we reveal to ourselves and to others, the inner vision which guides us as a nation. And where there is no vision, the people perish.”

Lyndon Johnson, on signing into existence the National Endowment on the Arts

\section{INTRODUCTION}

Unlike classical art, which remain fresh for each generation, the arts have always operated in an environment of uncertainty (Burton, 2003). The needs and preferences of audiences have changed - alternatives for arts and entertainment activities have mushroomed, new technologies for interacting with digital content continue to proliferate, and the demographic characteristics of consumers are becoming more diverse. Furthermore, consumers increasingly expect personalised and individual control over their experiences (NovakLeonard \& Brown (2011).

Controversies over high art versus popular culture have always been an inherent part of the challenges of arts organisations (Scheff \& Kotler, 1996). Attendance to art activities is declining for all age groups, not just the young and well-educated, so the traditional predictors of attendance no longer suffice as a model for contemporary art organisations (Jenkins et al., 2009). For a long time, art organisations could rely on public subsidies and were protected from pressures to respond to market changes to ensure their existence. The system of public subsidies made art organisations less alert to changes in consumer behaviour and to competition from the ever-expanding entertainment industry. To respond to commercial pressures and continue to provide an impartial public service, art organisations 
have little choice but to develop marketing strategies to stabilise and diversify their funding sources (Eckersley, 2008; Boorsma \& Chiaravolloti, 2010).

This paper will first explore the background to art marketing, followed by the presentation of a conceptual framework for the marketing of art based on participation and co-creation. Next, each of the components in the framework will be discussed and positioned within the whole. Finally, the paper will end with conclusions and areas of further research.

\section{BACKGROUND}

Traditionally, governments promoted participation in cultural activities as a way of developing communities (Reeves, 2002; Bianchini, 1993). In the early 1980s, when the community welfare model could no longer serve the arts, bureaucrats, practitioners and academics stepped in and developed the economic/cultural industry model (Caust, 2003). This led to the use of the terms "cultural industries" (in Australia) or “creative industries” (in the United Kingdom) to describe all activities connected with the arts, including a broad range of activities such as publishing, broadcasting, fashion, multi-media, journalism, publishing, the popular music industry and both commercial and not-for-profit art activity (Caust, 2003).

To justify government support for the arts, the need to prove art which also has economic benefits, has become prominent, and art policy has been expressed in terms of economic benefits and job creation (Reeves, 2002). This emphasis on the economic value of the arts as opposed to its intrinsic value has led to confusion and division in the sector (Caust, 2003). Furthermore, the tendency of Western governments towards evidence-based policy-making and impact studies to measure and assess the socio-economic impact of subsidised art has resulted in ongoing debate over how to assess the value of publicly funded arts projects (Belfiore \& Bennett, 2008, Bakhshi et al., 2009).

Charitable organisations are designed to enhance the public good, funded in part by government, private donations, and pricing of services (Hughes \& Luksetich, 2004). The charitable aspect of art organisations calls to mind politics, community, rights and responsibilities, and, in their civic role, their effect on people and places (Doeser \& Vona, 2016). Within or between these various groups, consensus of values or the sharing of a common goal is not a given. 
The bulk of activity undertaken to support and understand the civic role of the arts seems to have occurred in the United States. One reason for this may be the absence of a long-standing infrastructure or tradition of public funding support for the arts, as is the case in the UK and in continental Europe. Participation in the cultural life of the community is a basic human right and for this reason Doeser and Vona (2016) suggest art organisations should develop their civic role by reaching out and becoming an active part of their communities, especially if they receive public funding or protection. Art organisations are also seen as neutral or third spaces and thus in a good position to articulate and enable social action in response to the imbalance present in our unequal and divided societies. As trust, engagement and investment in traditional civic organisations such as churches, political parties appear to be declining, arts and cultural organisations represent a last resort through which to mobilise and inspire people in democratic processes.

Austerity, the lack of funding, and a fundamental shortage of attention and skills assigned to the arts create barriers to civic engagement. Furthermore, the disconnect between artists and communities regarding what art is and what art does, the unfavourable association between art and privilege, and art's hesitance to lead and be confident about the arts' contribution also hamper civic engagement. The continued trend in the UK of cuts to public services under the premise of austerity and the ongoing push from policymakers and the public for greater measurable benefits from investment in the arts are likely to place an ever-increasing emphasis on art organisations to develop their ‘civic role’ (Doeser \& Vona, 2016).

One way in which art organisations can develop their civic role is through marketing. Research into the marketing of arts includes various marketing approaches, analyses of consumption behaviour, and the socio-economic impact of art; nowhere is there a comprehensive framework of the various elements at play in the arts organisational landscape.

To address this gap, we provide a conceptual framework to guide government, funding bodies and art organisations in the development of contemporary marketing strategies based on audience participation. Next, we discuss each of the elements within the framework and how they interlink.

\section{A FRAMEWORK FOR ARTS MARKETING}

The Arts Marketing Framework (Fig. 1) provides a view of art organisation in relation to its funding partners and audiences. The framework also proposes the use of social media and 
collaboration to create social value. Finally, the framework highlights the role of selfconstrual in the process of value creation. A positive change in social value will enhance a sense of wellbeing and affiliation within the group.

Fig. 1. Arts marketing framework

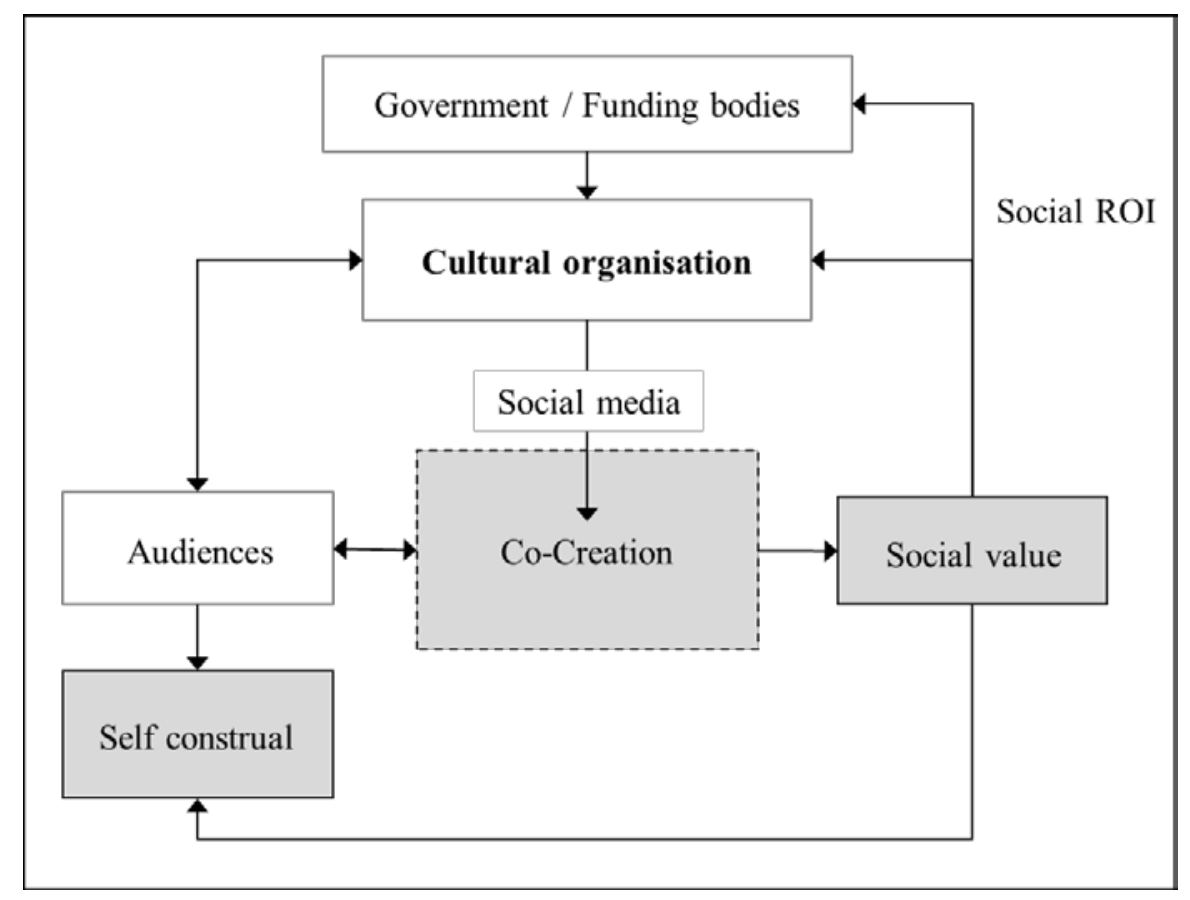

\section{Government/Funding bodies}

The arts are typically distributed through non-profit organisations, managed by artistic professionals, governed by influential trustees, and supported in large by funders (Scheff \& Kotler, 1996). Many European states emphasise public funding, whereas the US prefers taxinduced private support, and the UK lies somewhere in between, encouraging private sponsorship and maintaining a distinctive arm's length approach of state support via autonomous semi-state agencies. The incremental nature of grants and funds causes a constant crisis in art organisations (Butler, 2000).

For many art organisations, their ongoing business depends on the participation of funding partners, and for them, these connections provide a vital lifeline. The art organisation must lead the process of engagement with funding partners - fully confident about the social value it delivers.

At the same time, art organisations that mainly depend on government or other funding, must reflect on their own culture of market orientation. An internal culture of market orientation will result in increased consumer satisfaction levels and in doing so, strengthen the case for 
funding (Gainer \& Padanyi, 2002). With austerity likely to prevail, art organisation develop creative funding solutions to become more self-sufficient and less dependent on subsidies. Engaging stakeholders in the funding process has the potential of opening additional channels. Marketing communications provide the link between art organisation and its funding partners. These communications must aim to increase the strength and collaboration in the relationships with funding partners.

\section{The cultural organisation}

Art organisations operate in a market characterised by a complicated mix of private and public support and resourcing, a diversity of audience, and critics on whose opinions art is highly dependent (Butler, 2000). The difference in skill levels of the artists or participants is blurring, the forms of artistic expression are becoming more diverse, and public perceptions and tastes are changing (Novak-Leonard and Brown, 2011). Experience and trust characteristics dominate in art organisations, and this high share of experience and trust characteristics of cultural services leads to a high-quality uncertainty and/or behavioural uncertainty on the part of the participant (Hausmann, 2012).

Boorsma and Chiaravolloti (2010) suggest that increasing audience participation has become one of the primary objectives of art policy in most Western countries. These changes have forced art organisations to become more responsive to market forces and to develop strategies to not only stabilise and diversify funding sources, but rather to increase customer satisfaction levels and attract resources (Boorsma \& Chiaravolloti, 2010; Camareno and Garrido, 2008; Gainer \& Padanyi, 2002). Furthermore, the increasing economic and social importance of the culture sector and the requirement for transparency and accountability as investment in culture increases, requires marketing to be central to the organisation's mission (Butler, 2000).

\section{Marketing of the arts considerations}

Traditionally art organisations have relied on tactical marketing with a greater focus on the promotional role of marketing (Conway and Whitelock, 2007). However, the widespread use of the Internet and social media requires a fresh approach to marketing. Against this backdrop, an art marketing strategy must include a fresh look at place and marketing communications, as well as consider the additional concepts of participation, principles or precepts for civic engagement. 
Place has significant implications for art organisations. Art activities no longer only occur in the context of a physical setting, but also in virtual settings, whether it is a car, concert hall, theatre, coffee houses or churches (Novak-Leonard and Brown, 2011). Novak-Leonard and Brown (2011) identify three basic categories of art activities: art attendance, personal art creation, and performance and art participation through electronic media. In addition to art attendance, individuals participate in art creation activities such as painting and sculpting, and photography, film- and video-making, among others. Research suggests the third category of art activities - participation through electronic media such as viewing or listening to a performing arts event, or accessing art performances or programming online - is the most prevalent mode of art participation in the US (Novak-Leonard and Brown, 2011). Place plays a critical role in building a sense of community, especially using technology to help build online communities in partnership with the public (Kolb, 2005).

Marketing communications now involve new platforms and tools which enable art organisations to blend reach, intimacy and engagement with consumers and influencers (Hanna et al., 2011). Therefore, art organisations can take full advantage of their owned media (for example website and social media sites) and earned media (word-of-mouth) to reach their intended goals (Corcoran, 2009).

Participation in art marketing is also unique. Technological, social, demographic and economic changes all influence how people participate in the arts. The context of public participation in the arts depends on the skill level of the artist or participant, the form of artistic expression, the setting in which the activity occurs, and the degree to which the individual exercises creative control over the activity (Novak-Leonard and Brown, 2011). Regarding the skill level of the artist, Leadbeater and Miller (2004) highlight the burgeoning of the professional amateur who engages in art with inventiveness and dedication. Traditionally viewed as falling outside the non-profit art infrastructure and commercial arts, the professional amateur will have a significant impact on shaping the $21^{\text {st }}$ Century. In the past, cultural organisations assumed they could use education to move cultural consumers further along the continuum of involvement. However, culture participants no longer want to only experience the product, they also want to contribute to the organisation through development of the art product, i.e. through affiliation, posting of reviews and comments, and uploading their personal art work (Jenkins et al., 2009).

The art organisation must become the hub for all three categories of participants of culture to share and engage in their own creation while at the same time, experiencing the culture that is 
the aim of the organisation (Kolb, 2005). Modern day culture participants are no longer satisfied to observe, but instead, they want to participate in recreational and leisure activities and have an equal voice in the organisation (Kolb, 2005; Dychtwald, 2003). In social engagement, the boundaries between artist, curators and publics are contravened, and the artistic control may shift between any of those involved (Froggett et al., 2011a). The art organisation must experiment with these boundaries, yet remain firm on its values and civic mission.

Finally, principles include the mixture and translation of individual and organisational core values into actions that will ultimately strengthen the organisation's civic role (Kaufman \& Horton, 2014). Being a neutral space with the capability of enabling social action will require explicit communication of the organisation's values.

\section{Audiences}

There is complexity in the arts organisation's stakeholder networks (Butler, 2000), and to deal with this complexity successfully, a strong, clear social and civic mission must underpin all social engagement strategies (Froggett et al., 2011a). According to Hatch and Schultz (2010), the art organisation's brand value is decided through the engagement of all its stakeholders, not only consumers. The art organisation must therefore sustain and adjust its brand commitment in line with developing stakeholder expectations and shifts in the external environment (Balmer, 2013). With or without the organisation's active involvement, the art organisation will be branded (Kolb, 2005).

To be a hub for art participation will involve open and honest two-way communication between the organisation and its audiences. Boorsma and Chiaravolloti (2010) suggest artists and art organisations perform three interrelated kinds of artistic functions for three main stakeholder groups: customers (artistic experiences), community (ongoing (re)construction of culture), and professions (adding to the development of the professional field of artistic disciplines). Fulfilling these functions can help to strengthen the relationships between the arts and key stakeholder groups, but their relevance is secondary when compared with the primary artistic functions of the art organisation. Many art organisations depend heavily on the efforts of external partners to be able to create and deliver the values expressed in the mission (Boorsma \& Chiaravalloti, 2010).

Research indicates that some of the most powerful work emerges from the reciprocal influences of partners. Sustaining these partnerships can be exacting and challenging on all 
sides, involving clashes of organisational culture and gaps in expectations and understanding which requires patience and skilled diplomacy (Froggett et al., 2011a). The art organisation must therefore develop strategies that foster co-creation, collaboration and a shared vision, which in turn will foster positive audiences' psycho-social motivations to engage in art.

\section{Self-construal}

Self-construal is typically defined as how individuals see the self in relation to others (Cross et al, 2011). Audiences engage in consumption behaviour in part to create their self-identity, and to present their self to others. The congruency between self-image and self-group associations will influence their consumption choices (Escalas \& Bettman, 2003; Swaminathan et al., 2007). According to Escalas and Bettman (2005), audiences use others particularly those with similar beliefs - as a source of information when establishing and evaluating their beliefs about the world.

Social identity theory (SIT) suggests that there is an emotional significance to the participant's identification with the group (Hogg, 2006; Tajfel \& Turner, 1979). The group behaviour displayed by members of groups as part of social identity processes lead to positive self-esteem and self-enhancement (Trepte, 2006; Abrams \& Hogg, 1988).

Consumer-brand relationships can be formed based on individual- or group-level connections. For example, a consumer's relationship with art may be based on the desire to express an individual-level unique identity, whereas a relationship with the art brand may be based on a group-level identity (e.g., an academy of ancient music or a ballet company). Research by (Swaminathan et al., 2007) suggests group-level associations such as memberships in art organisations and brand communities may provide additional bases for building relationships with consumers and enhancing consumer engagement (Swaminathan et al., 2007).

The strong correlation between the individual connections in these groups and brand choices suggests individuals are more likely to follow patterns of art consumption where strong connections with the reference group exist. Art organisations should capitalise on these ingroup associations.

These psycho-social characteristics, or self-construals, can be used to analyse the relationships between art stakeholders as well as the ways in which cultural participation and engagement can lead to enhanced reflectiveness and understanding of individuals as both a cognitive and affective agent (Crossick \& Kaszynska, 2016). 
Contemporary art marketing efforts must aim to understand individual and community engagement in terms of their relationships with the art organisation and its members. The art organisation must understand the psycho-social characteristics of audiences, and promote contemporary approaches for audiences engagement and participation, providing avenues of digital conversation, collaboration and cooperation to delineate, convey and deliver valuable experiences to their audiences, and consider that engaging consumers in their marketing communications and value creation will increase the effectiveness of the art organisation's communication.

\section{Social media participation}

The advent of the internet and social media created a change in cultural organisations' communications and engagement with their audiences; and the constant developments in digital cultures represent a challenge for organisations to provide more flexible, creative and empowering methods of delivery and audience engagement (French \& Runyard, 2011). In his report for the UK’s Department for Culture, Media and Sport (DCMS), McMaster (2008) acknowledges the desirability of using digital marketing tools to develop audiences. Digital media has the capacity to connect people across time and space, facilitate social networks and personal communities, and bridge class and racial gaps (Mehra et al., 2004).

Social media has facilitated a new paradigm for art communications, evolving from paid oneto-many cultural organisation marketing or paid media to consumer-generated many-to-many communications regarded as earned media, where organisations do not pay or control the placement and distribution of messages (Thomas, 2004; Stephen \& Galak, 2012). In the arts and culture environment, opinions of peers about artistic and cultural manifestations may have more credibility and greater impact than the communications of the cultural organisation (Trusov et al., 2009).

Hausmann (2012) suggests that creating buzz for art and cultural organisations not only fosters word-of-mouth among consumers which can be consider an effective strategy with regards to experience and trust characteristics of service providers such as museums, theatres or orchestras. This approach can also help the reduction of quality and/or behaviour uncertainty from a consumer's perspective.

The continued shortage of resources in the cultural sector can benefit from web-based applications which can facilitate viral marketing and stimulate word-of-mouth (Hausmann, 2012). Cultural organisations can use affiliations in online communities and crowdsourcing to 
solve their fundraising problems and circulate information through sharing by way of podcasts, posted reviews and links to review websites, whilst art consumers can express themselves on the organisation's website and share information (Hausmann, 2012).

Art organisations should incorporate all aspects of social media, such as social networks, social publishing and news, social commenting in blogs, social niche communities, social knowledge (Wikipedia), social bookmarking, social search and social commerce (iTunes, Spotify) - to build relationships with audiences; allowing people to participate in the creation and communication of art manifestations and therefore developing audience's engagement by feelings of cooperation.

Although Hausmann (2012) points out that the shortage of resources, cost-benefit ratio of hiring additional qualified staff, measurement of success, and the rigid structure and hierarchy of art organisations all remain limiting factors for the use of social media, art organisations have no choice but to be in tune with developments in technology, and to understand the drivers for audience participation and engagement in artistic and cultural programmes.

\section{Co-creation}

Perhaps one of the most significant changes in consumer digital access to art and cultural work is related to the consumer's ability to co-create artistic and cultural content (Crossick \& Kaszynska, 2016). A major implication of this co-creation is that art organisations can work in conjunction with new or existing consumers in a process of mutual value creation. Bresford and Carthew (2011) suggest this value takes the form of artistic manifestations which may include crowd-sourced films, user generated content (UGC) for museums and galleries, as well as a collective or collaborative experience in theatre or performing arts spaces. Such high-quality interactions with consumers have the potential of creating value for all stakeholders involved as well as generating new sources of competitive advantage for the organisation (Prahalad and Ramaswamy, 2004).

Co-creation empowers consumers into a "democratisation" of content creation and distribution, within a public forum, resulting in a group of people who are in control of an interactive model of communication among them and with art organisations (Harwood and Garry, 2010), and the art organisation must leverage the creativity and the power of consumer networks for its own benefit (Christodoulides et al., 2011). For example, The San Francisco Symphony’s Community of Music Makers program invites audiences to play and sing on 
their stage, inspiring thousands of amateurs to re-connect with music and connect with their local orchestra. Encouraging creative consumer involvement and empowerment through cocreation will result in relationship-building experiences with a positive effect on audience assessment of the value of art (Joachimsthaler \& Aaker, 1997; Füller et al., 2009); with benefits for both art organisation and audiences augmenting the social value of the arts.

\section{Social value}

The concept of 'value' in the arts is not as clear as in business. The Arts Council England suggests that attempting to quantify the value of art to justify their contribution to audiences' collective and individual lives have always been problematic (England, 2014). Even though funds directed to supporting the cultural life of a nation translate into the development of creative industries, job creation, and the development of cultural identity, stakeholders are most concerned about the effective use of public money and how art findings will contribute to wider social and economic goals (Crossick and Kaszynska, 2016). Whereas consumer supremacy is a core concept of marketing, in non-profit contexts, the funding by public and private bodies must be translated into a definition of value, and therefore subject to criticism (Butler, 2000).

Social value consists of resources within communities which are created through the presence of the following interlinking elements: high levels of trust, reciprocity, shared norms of behaviour, shared commitment and belonging, formal and informal social networks, and effective information channels which may be used by individuals and groups to facilitate actions to benefit individuals, groups and the community in general (Kay, 2006). Art organisations can use social value to include, support, develop and create communities.

For art organisations, trust will be an important element. Both co-creation processes and the interaction through social media will require high levels of trust. Individuals tend to work with others and organisations who share the same values. Furthermore, individuals and organisations who share the same values can form trusting relationships faster, thus accelerating the establishment and development of social capital (Kay, 2006). As participation with other organisations is inherent in the Marketing Framework, such participation will depend on the trust relationships between individuals in those organisations. A breakdown in trust will have a negative impact on social value. 
According to Gittel and Vidal (1998), the two dimensions of social value are 'bonding' social value which develop within a group and binds individuals, groups and organisations together, and 'bridging' social value which allows art organisations to reach out and network with other groups and entities. The 'bonding' social value will aid self-construal and affiliation within groups.

Art organisations must understand the level of social value within a community as patterns will depend on the historical development of that community (Kay, 2006). Furthermore, prevailing attitudes of powerful local influences will have a bearing on social capital.

Finally, as a hub for art participation, art organisations can facilitate collective action within communities. The value the organisation represents is the combined result of the co-creation that takes place through various networks and relationships. As the access routes into art organisations and its resource increase, the greater the transparency for and the involvement of the stakeholders will become (Hatch \& Schultz, 2010).

Social value feeds back to audiences' self-construal and to funding partners, by promoting high levels of trust, reciprocity, shared norms of behaviour, shared commitment and belonging, formal and informal social networks for the former and by providing social ROI benefits to audiences, art organisations and the community in general, for the latter.

\section{Social return on investment}

Experiences in the arts are processed cognitively, emotionally and spiritually and are therefore highly subjective, thus, making the intrinsic value of art difficult to articulate in terms of mass 'outcomes' (Holden, 2006). However, the return on investment of public funding in the arts has been the subject of much debate (Sawers, 1993; Henriques, 2014; McPherson, 2015), resulting in constant scrutiny of governments and funding.

Considering the positive social effects of art manifestations and their contribution to the sustainable development of communities, the Marketing Framework requires the application of the Social Return on Investment structure to measure the social, environmental and economic costs-benefits of art funding.

Social return on Investment (SROI) incorporates socio-economic and environmental elements into decision making, to provide a more complete picture of how value is created (Wood \& Leighton, 2010). SROI is based on stakeholders assigning financial value to goals identified 
by stakeholders as important, and gives people a voice in the allocation of resource decisions (Arvidson et al., 2010).

The Arts Marketing Framework (Fig. 1) suggests that by applying SROI in the arts industry, funding and cultural organisations may be able to forecast the amount of social value creation of their activities if the intended outcome is focused on stakeholder engagement through communication and co-creation (Nichols et al., 2012). The framework suggests that SROI promotes better communication and engagement between stakeholders and raises community awareness, leading to increased understanding of expectations and what means are required and available to reach envisioned goals (Arvidson et al., 2010; Nichols et al., 2009; King, 2014).

To engage and develop audiences, art organisation must demonstrate the value of the taxpayers' investment, by way of a return on increased audience numbers, repeat business, depth of experiences, positive reviews, and most importantly, a reduction in barriers between participants and their connection with the arts (Bresford \& Carthew, 2014).

Therefore, through a social accounting and audit process art organisations can understand their impact on the surrounding community and build accountability by engaging with its stakeholders. In this way, the organisation can prove its value and improve its performance (Mulgan, 2010), as a result a positive SROI will justify further funding schemes.

\section{CONCLUSIONS}

To achieve their social objectives and financial goals, and deliver value to each stakeholder, the main aim of art marketing should be to optimise the consumer's co-creative role (Boorsma, 2006; Boorsma \& Chiaravolloti, 2010). Marketing strategies should centre on audience experiences that foster conversation, participation and cooperation. This will require an understanding of the role of the art consumer in art production and communication process, as well as knowledge of the psycho-social characteristics of various audiences.

The issue of measurement remains a contentious one. Eckersley (2008) points out that real change to the system of cultural provision cannot be made without increased and sustained financial support. Attainable procedures for measuring and judging the success or failure of art will require politicians, policymakers, cultural providers, auditors and funders to think outside the box (Eckersley, 2008). 
Furthermore, governments need to be reminded again about why they are involved in the arts and what their role is in that transaction. Attempts by governments to control, manage and rationalise the arts sector may pervert the very practise of art itself. Art must lead the communication of art policy and practise in the language and symbolism of artists, rather than within the context of the economic/managerial style of jargon of the day (Caust, 2003).

Art organisations must find new ways to overcome the policy tensions between excellence and value. The two can exist side-by-side. Art-based participation and engagement offer culturally marginalized people new ways of expressing their feelings. Art extends the capacity for meaning, and therefore communication, of the unarticulated inner worlds of individuals and groups. In doing so, art offer individuals a sense of authenticity and a voice (Froggett et al., 2011a; Froggett et al., 2011b).

And finally, art and culture can only thrive when the offering is relevant (Eckersley, 2008). Relevance will require careful reflection of art organisation's identity and offering, as well as the participation of stakeholders in the development and marketing of art.

\section{FUTURE RESEARCH}

The arts marketing model (Fig. 1.) provides a conceptual framework to understanding the various elements at play in the marketing of art. First, there is a need and opportunity to explore the impact of self-construal on the effects of art marketing and advertising. Selfconstrual has an impact on art consumption and the effect of marketing communications. Empirical research is required to ascertain the level of impact of these characteristics in existing art marketing strategies and provide an understanding on how to manage different audiences. 
Second, another avenue is to survey the use of social media and co-creation by art organisations in, for example, the UK and the USA. Next, with regards to co-creation, it would be necessary to understand the level of involvement of audiences with existing or future strategies including consumers in value creation. From a psychosocial perspective, self-construal is believed to have an impact on how individuals engage with their groups, and thus, ascertaining the levels of influence of self-construal in audience participation will provide art organisations with a clear understanding of audience engagement.

Third, concerning the effects of co-creation experiences in value creation, empirical research is required to ascertain the implications for interactive marketing. It is necessary to establish how/where in art marketing co-creation process value is established.

Finally, an analysis of the Social Return of Investment for specific cultural organisations should provide valuable insights. For instance, SROI has been applied to other non-profit organisations such as public libraries, sport and recreation services, and health organisations and not directly to arts and cultural organisations. Such a study will provide support for government and public funding for the arts. 


\section{REFERENCES}

Abrams D, Hogg MA. 1988. Comments on the motivational status of self-esteem in social identity and intergroup discrimination. European Journal of Social Psychology, 18: 317-334. ArtsFwd 2016. National innovation summit for arts and culture. [Online] Available from http://artsfwd.org/summit/session/co-creating-with-the-public/ [Accessed on 20 December 2016].

Arvidson M, Battye F, Salisbury D. 2014. The social return on investment in community befriending. International Journal of Public Sector Management, 27: 225-240.

Arvidson M, Fergus K, McKaym S, Moro D. 2010. The ambitions and challenges of SROI, $\begin{array}{lllll}\text { working } & \text { paper } & \text { [Online] Available }\end{array}$ http://eprints.mdx.ac.uk/7104/1/The_ambitions_and_challe [Accessed 29 July 2016]

Bakhshi H, Freeman A, Hitchen G. 2009. Measuring intrinsic value-how to stop worrying and love economics.

Balmer JM. 2013. Corporate brand orientation: What is it? What of it? Journal of Brand management, 20: 723-741.

Belfiore E, Bennett O. 2010. Beyond the "Toolkit Approach": Arts Impact Evaluation Research and the Realities of Cultural Policy- Making. Journal for Cultural Research, 14: 121-142, DOI: 10.1080/14797580903481280.

Beresford S, Carthew W. 2014. Arts, leisure and entertainment marketing and communications. Exploring Public Relations 3ed. Thench R, Yeomans L. ed. Pearson education: Harlow.

Berger J, Heath C. 2007. Where consumers diverge from others: Identity signaling and product domains. Journal of Consumer Research, 34: 121-134.

Bianchini F. 1993. Remaking European cities: the role of cultural policies. Cultural policy and urban regeneration: The west European experience: 1-20.

Boorsma M. 2006. A strategic logic for arts marketing: Integrating customer value and artistic objectives. International Journal of Cultural Policy, 12: 73-92.

Boorsma M, Chiaravalloti F. 2010. Arts marketing performance: An artistic-mission-led approach to evaluation. The journal of arts management, law, and society, 40: 297-317. 
Burton C. 2003. Scoping the challenge: Entrepreneurial arts management in times of uncertainty. The Journal of Arts Management, Law, and Society, 33: 85-195.

Butler P. 2000. By popular demand: Marketing the arts. Journal of Marketing Management, 16: 343-364.

Byrnes JP. 2011. Public Participation in the Arts and the Role of Technology. New York: Nova Science.

Camareno C, G M.J. 2008. The role of technological and organizational innovation in the relation between market orientation and performance in cultural organizations. European Journal of Innovation Management, 11: 413-434.

Caust J. 2003. Putting the "art" back into arts policy making: how arts policy has been “captured” by the economists and the marketers. The international journal of cultural policy, 9: $51-63$.

Christodoulides G, Jevons C, Bonhomme J. 2012. Memo to Marketers: Quantitative Evidence for Change. How User-Generated Content Really Affects Brands. Journal of Advertising Research, 52: 53-64.

Conway T, Whitelock J. 2007. Relationship marketing in the subsidised arts: the key to a strategic marketing focus? European Journal of Marketing. 41: 199-222, DOI: http://dx.doi.org/10.1108/03090560710718184.

Corcoran S. 2009. Defining earned, owned and paid media. Forrester Research.

Cross SE, Hardin EE, Swing BG. 2011. The what, how, why, and where of self-construal. Personality and Social Psychology Review, 15: 142-179. DOI: 10.1177/1088868310373752.

Crossick G, Kaszynska P. 2016. Understanding the value of arts and culture. The AHRC cultural value project.

Doeser J, Vona V. 2016. The civic role of arts organisations. King's College London. [online] Available from http://gulbenkian.org.uk/files/03-02-16The\%20civic\%20role\%20of\%20arts\%20organisations\%20SUMMARY.pdf [Accessed 18 July 2016 at 18h01).

Dychtwald M. 2003. Cycles: How we will live, work, and buy. Simon and Schuster.

Eckersley S. 2008. Supporting excellence in the arts: from measurement to judgement. Cultural Trends, 17: 183-187. DOI: 10.1080/09548960802362108 
England, Arts Council. 2014. The Value of Arts and Culture to People and Society.

Escalas JE, Bettman JR. 2005. Self-construal, reference groups, and brand meaning. Journal of Consumer Research. 32: 378-389.

Escalas JE, Bettman JR. 2003. You are what they eat: The influence of reference groups on consumer connections to brands. Journal of Consumer Psychology. 13: 339-48.

French Y, Runyard S. 2011. Marketing and public relations for museums, galleries, cultural and heritage attractions. Routledge.

Froggett L, Little R, Roy A, Whitaker L. 2011a. New model visual arts organisations \& social engagement. Psychological Research Unit, Preston, and University of Central Lancashire.

Froggett L, Farrier A, Poursanidou K. 2011b. Who Cares: Museums, Health and Wellbeing Research Project. A Study of the Renaissance North West Programme, Psychosocial Research Unit, University of Central Lancashire. Accessed August 7: 2013.

Füller, J, Mühlbacher H, Matzler K, Jawecki, G. 2009. Consumer empowerment through internet-based co-creation. Journal of Management Information Systems, 26: 71-102.

Gainer B, Padanyi P. 2002. Applying the marketing concept to cultural organisations: an empirical study of the relationship between market orientation and performance. International Journal of Nonprofit and Voluntary Sector Marketing, 7: 182-193.

Gittel R, Vidal A. 1998. Community Organising: Building Social Capital as a Development Strategy. Sage Publications: Newbury Park, CA.

Hanna R, Rohm A, Crittenden VL. 2011. We're all connected: The power of the social media ecosystem. Business Horizons, 54: 265-273.

Harwood T, Garry T. 2010. 'It's Mine!'-Participation and ownership within virtual cocreation environments. Journal of Marketing Management, 26: 290-301.

Hatch MJ, Schultz M. 2010. Toward a theory of brand co-creation with implications for brand governance. Journal of Brand Management, 17: 590-604.

Hausmann A. 2012. Creating 'buzz': opportunities and limitations of social media for arts institutions and their viral marketing. International Journal of Nonprofit and Voluntary Sector Marketing, 17: 173-182. 
Henriques A. 2014. Social Value: A sustainability buzzword without a meaning? The Guardian [Online] Available at: https://www.theguardian.com/sustainable-business/socialvalue-impact-buzzword-sustainability [Accessed 28 July 2016]

Hirschman EC. 1983. Aesthetics, Ideologies and the Limits of the Marketing Concept. Journal of Marketing, 47: 45-55.

Hogg MA. 2006. Social identity theory. Contemporary social psychological theories, 13: 111-369.

Holden J. 2006. Cultural value and the crisis of legitimacy: why culture needs a democratic mandate. [Online] AEMOS. Available from: http://www.demos.co.uk/files/Culturalvalueweb.pdf. [Accessed on 28 August 2016].

Hughes P, Luksetich W. 2004. Nonprofit arts organizations: Do funding sources influence spending patterns? Nonprofit and Voluntary Sector Quarterly, 33: 203-220.

Jenkins H, Purushotma R, Weigel M, Clinton K, Robison AJ. 2009. Confronting the challenges of participatory culture: Media education for the 21st century. Mit Press.

Joachimsthaler E, Aaker D. 1997. Building Brands Without Mass Media. Harvard Business Review 75: 36-46.

Kaufman I, Horton C. 2014. Digital Marketing: Integrating Strategy and Tactics with Values, A Guidebook for Executives, Managers, and Students. Routledge.

Kay A. 2006. Social capital, the social economy and community development. Community Development Journal, 41: 160-173.

King N. 2014. Making Case for sport and recreation services: The utility of social return on investment analysis. International Journal of Public Sector Management, 27: 152-164.

Kolb BM. 2005. Marketing for cultural organisations: new strategies for attracting audiences to classical music, dance, museums, theatre \& opera. Cengage Learning EMEA.

Leadbeater, C., and Miller, P. (2004). The Pro-Am revolution: How enthusiasts are changing our society and economy. Demos.

Lloret Romero N. 2011. ROI. Measuring the social media return on investment in a library. The Bottom Line, 24: 145-151.

McMaster B. 2008. Supporting Excellence in the Arts. Department for Culture, Media and Sport. 
McPherson D. 2015. A Critic’s Plea: stop all arts funding now. The Guardian [Online] Available at: http://www.telegraph.co.uk/news/politics/conservative/11630643/A-criticsplea-stop-all-arts-funding-now.html. [Accessed 03 August 2016]

Mehra B, Merkel C, Bishop AP. 2004. The internet for empowerment of minority and marginalized users. New media \& society, 6: 781-802.

Mulgan G. 2010. Measuring social value. Stanford Soc Innov Rev, 8: 38-43.

Nicholls I, Lawlor E, Neitzert E, Goodspeed, T. 2012. A guide to Social Return on Investment, $2^{\text {nd }}$ ed. Matter \& Co. [Online] Available at: http://socialvalueuk.org/what-issroi/the-sroi-guide [Accessed 20 July 2016]

Novak-Leonard JL, Brown AS. 2011. Beyond Attendance: A Multi-Modal Understanding of Arts Participation. Based on the 2008 Survey of Public Participation in the Arts. Research Report\# 54. National Endowment for the Arts.

Prahalad C, Ramaswamy V. 2004. Co-creation experiences: The next practice in value creation. Journal of interactive marketing, 18: 5-14.

Reeves, M. (2002). Measuring the economic and social impact of the arts: a review. London: Arts Council of England.

Sawers D. 1993. Should the Taxpayer Support the Arts? The Institute of Economic Affairs: Goron Pro-Print Co LTD: Lancing, West Sussex.

Scheff J, Kotler P. 1996. Crisis in the Arts: The Marketing Response. California Management Review, 39: 28-52. DOI: 10.2307/41165875.

Stephen AT, Galak J. 2012. The effects of traditional and social earned media on sales: A study of a microlending marketplace. Journal of Marketing Research, 49: 624-639.

Swaminathan V, Page KL, Gürhan-Canli Z. 2007. “My” brand or “our” brand: The effects of brand relationship dimensions and self-construal on brand evaluations. Journal of Consumer Research, 34: 248-259.

Tajfel H, Turner JC. 1979. An integrative theory of intergroup conflict, The social psychology of intergroup relations, 33: 74 .

Thomas GM. 2004. Building the buzz in the hive mind. Journal of Consumer Behaviour 4: 64-72.

Trepte S. 2006. Social identity theory, Psychology of entertainment: 255-271. 
Trusov M, Bucklin RE, Pauwels K. 2009. Effects of Word-of-Mouth Versus Traditional Marketing: Findings from an Internet Social Networking Site. Journal of Marketing 73: 90102.

Wood C, Leighton D. 2010. Measuring social value: the gap between policy and practice. Undercurrent, 2: 7. 